\title{
INFLUENCE OF EXTENSION AGENTS' AND FARMERS' COMMUNICATIONS FACTORS ON THE EFFECTIVENESS POULTRY TECHNOLOGY MESSAGES
}

\author{
Ofuoku AU \\ Department of Agricultural Economics and Extension, Delta State University, Asaba Campus, Asaba, Delta \\ State, Nigeria
}

Accepted : 15 December 2011

\begin{abstract}
This study was conducted in Delta State to determine the influence of extension agents' and farmers' communication factors on effectiveness of production technology messages. One hundred and eighty (180) poultry farmers and forty six (46) extension agents were selected for this study. The poultry production technology messages communicated to farmers included climate change adaptation methods, waste management, health management, predator control and improved breeds. The extension agents and poultry farmers were rated as being generally good in human relations, communication skills and role performances. The test of hypothesis showed positive significant influence of the communication skills of extension agents and poultry farmers on level of adoption of the poultry technologies hence poultry production technology messages. It was recommended among others that extension agents should provide follow up appointment for farmers, more extension agents should be trained and employed, farmers should be encouraged to allow their spouses share information with other farmers and the communication skills of the extension agents and fairness should be sustained.
\end{abstract}

Key words: Communication skills, Message effectiveness, Prevention Motivation theory, Adoption

\section{INTRODUCTION}

Communication planning is critical for media outreach, but its value reaches far beyond traditional external relations. For organizations like the Delta State Agricultural Development Programme (DTADP), taking time to formulate a consistent and effective poultry production technology message can be a valuable investment that enhances development, media advocacy and public relations, direct service and outreach efforts. Developing an effective poultry technology message can help agricultural extension agency team of staff, volunteers, donors and supporters articulate coherent and consistent idea about why organization works and its mission matters (Ofuoku 2010).

According to Hunt (2006), a message is effective if it persuades a particular audience. An effective poultry technology message is the one that prompts poultry farmers to act in a way that supports the goals of extension agencies and other stakeholders. On the receipt of such a message, if the target farmers change behavior in a desired manner, it means the message is effective and the content there of will be adopted by them.

Poultry production technology messages are those in which poultry farmers and other stakeholders through planned use of strategies and processes of communication with the goal of achieving agricultural development. The poultry production technology messages communicated to farmers range from environmental issues, health, predator prevention to exotic breeds (Ofuoku 2010).

The extension agents' and farmers' communication factors include human relations, communication behavior and skills, and role performance. The factors, according to Waisboard (2006), Agbamu (2006), Olowu (1989) could either enhance or jeopardize the success of a development programme. It therefore means that they are salient to effectiveness of messages.

In spite of the well designed and promoted programme, the needs and aspirations of poultry farmers to improve their farming systems have been stagnated (Adefuye and 
Adedoyin 1993). Be that as it may, it means the poultry production technology messages disseminated to them are not Effective. It is suspected that the poultry production technology messages are affected by the communication factors relating to extension agents and the farmers. The result of this study will contribute as a guide for poultry production technology message design and dissemination by DTADP and other extension agencies in the world, especially in the developing nations.

Objectives of the Study: The major objective of the study is to ascertain the influence of extension agents' and farmers' communication factors on effectiveness of poultry technology messages . The specific objectives are to:

identify the poultry production technology messages communicated to farmers,

evaluate the human relations, communization behavior and skills, and role performance of extension agents and farmers

determine the adoption levels of the production technologies borne by the messages

ascertain the effectiveness of the messages and the influence of extension agents' and farmers' communication factors on effectiveness of the messages

Hypothesis: The extension agents' and farmers communication factors do not influence effectiveness of poultry production technology messages.

\section{METHODOLOGY}

This study was carried out in Delta State, Nigeria. The state has high concentration of poultry farmers that are served by the Delta State Agricultural Development Programme (DTADP). The state is demarcated into three agricultural zones - Delta North, Delta Central and Delta South Agricultural Zones by the DTADP.

Random sampling method was used to select the respondents from among the 1800( Delta North $=725$;Delta Central $=945$ and Delta South=144) poultry farmers registered with the three DTADP zonal headquarters located in each of the three agricultural zones, on the basis of $10 \%$ from each zone. This resulted to
180 poultry farmers. Purposive sampling was used to select 46 extension agents covering the various extension blocks where these farmers were located. Purposive sampling was used in order to select the extension agents who have been working with these farmers for minimum of ten years as these ones know the farmers better than those who have not spent up to ten years with them. Consequently, 246 respondents were arrived at and used for the study.

The data were collected from the respondents using questionnaire and structured interview schedule. Both instruments were pre-tested for reliability with cronbach's alpha coefficient. The results of the correlation between the first responses and the second responses showed a high level of correlation for structured interview schedule $(\mathrm{r}=0.82)$ and the questionnaires $(\mathrm{r}=0.85)$.

The data collected were analyzed with the use of descriptive statistics such as frequency counts, percentages, and means derived from 5 point likert's scale, thus very good $=5$; good $=4$; fair $=3$; poor $=2$; and very poor $=1$. The hypothesis was used to address objective V. The hypothesis was tested using Pearson Product Moment Correlation (PPMC).

\section{RESULTS AND DISCUSSION}

\section{Poultry production technology messages communicated to the respondents}

The poultry production technology messages communicated to farmers included messages on climate change which consisted of tree planting $97.2 \%$, installation of fan $\left(92.2^{\circ} \mathrm{C}\right)$ and constant supply of fresh water $(100.0 \%)$; under waste management, $92.2 \%$ of the farmers received messages on recycling of poultry droppings. On health management, $100 \%$ got messages on bird flu control and prevention. Under predator control, $78.3 \%$ heard messages on the use of sliced garlic. Under exotic breeds $25 \%$ got messages on Abro, $6.7 \%$ on Arboracre, $28.3 \%$ on Hubbard strains, 23;9\% on Harco, $18.9 \%$ on Isa brown, $13.3 \%$ on Shaver star cross and $18.3 \%$ on Black Olympia.

Tree planting messages were transmitted to the farmers so as to the effect of heat. 1-Jeat can cause stress for the birds and this affects their 
feed intake and laying capacity adversely. According to Izunobi (2002) a substantial increase in environmental temperature will reduce growth rate, egg production, size and shell quality.

Trees also reduce the effect of wind on pens and installations of fans reduce heat in the pens too. Excessive wind known as wind hedge poses inescapable problem to many poultry farms from the southern coastline to the northern Sahara fringe (Izunobi 2002).

Constant supply of water to chickens reduces heat stress. The water, especially when cool reduces the body temperature to the normal level required by the chickens. Waste management messages were to proffer solution to the problem of waste disposal. Waste when recycled in form of manure is beneficial for growing crops and reduces the effects of effluents from the dropping on the climate.

A bird flu prevention message was meant to prevent and control its outbreak, especially when the disease is zoonotic. Garlic was recommended in messages to farmers to prevent predators like snake. Snakes, on entering pens kill birds and consumer eggs. This method of predator control has the advantages of being environmental friendly.

Messages on exotic (improved) breeds of chicken were sent to the farmers for their superior qualities of rapid growth and high productivity in terms of meat and eggs. The ones mentioned are superior to the pure breeds of exotic breeds as they are hybrids of the pure exotic breeds.

\section{Human Relation, Communication Skills, and role performance Extension agents as rated by poultry farmers}

On human relations the receivers (poultry farmers) rated the extension agents (source/ sender) (Table 1) as being very good in the feeling of togetherness with farmers (mean= 3.97), manner of approach to influence acceptance of technology $($ mean $=3.82)$ and general truthfulness and sincerity (mean=3.87). The feeling of togetherness with the farmers creates the feeling of oneness in them and makes them to become open to the extension agents creates confidence in the farmer so that they do not hide their problems and aspirations from the extension agents. This is for the fact that they then see themselves as a family.

The manner of approach used to influence farmers to accept technology is very important. It is a function of how the extension agents market the technology to the farmers. The way he sends the message may either motivate farmers to adopt or discourage them against adoption. It is always better when messages are persuasively passed with respect for the farmers. Truthfulness and sincerity on the part of the extension agents make farmers to develop interest in them. This is congruent with Tladi (2004) who discovered that the above qualities were stressed by farmers as part of the criteria for evaluating the performance of extension agents. According to Agbamu (2006), credibility of the communicator will determine the attitude of the people.

To the poultry farmers, with respect to communication skills, the extension agents were Very good in the display of empathy (mean=3.76), encourage of questions and enquires (mean=3.72), use of key commu nicator $($ mean $=3.77)$, credibility $($ mean $=3.66)$, personality (mean=3.51), use of common language and expression (mean $=3.67)$, clarity and comprehensibility (mean=3.65), Display of adequate communication skill generally (mean=3.72) and involvement of clientele (mean=3.64). The farmers rated the extension agents as being good in the used of feedback (mean=3.27), listening skill (mean=3.23) and maintenance of continuous communication with the farmers (mean=3.21). However, they were rated as being fair in provision of followup appointments with farmers. In the use of entertainment, they were rated poorly $($ mean $=2.88)$.

Genuine display of empathy helps to win the confidence of farmers. Encouragement of questions and enquires helps extension agent to further Clarify the areas not understood farmers, thereby promoting message effectiveness. Agbamu (2006) opined that this also translates into understanding their educational level, norms and beliefs. Credibility of the extension agents as a communicator creates avenue for him or her to gain confidence and trust of his clientele 
(Williams et al. 1984).

The extension agent needs to have good personality in order to win the respect of the farmers. He should be seen as somebody who respects himself by behaving responsibly. Agbamu (2006) suggests that he should have great respect for himself.

The use of feedback enables the sender (extension agent) to know if the message is understood the way he expects it to be understood. He is able to know, through, feedback if the intended meaning is given to the message.

The language used by the extension agent as a communicator should be understood by the farmers (receivers). Williams et al. (1984) as cited by Agbamu (2006) stated that a good communicator should speak clearly and use terms and language the receivers will understand. He should view what he is doing or saying from the stand point of his audience (Agbamu, 2006).

Involvement of the clientele in the development of messages gives room for the message to be relevant to the clientele. The farmers know their problems and aspirations better then the extension agents. This is in accordance with the saying that he who wears the shoe knows where it pintches. Waisbord (2006) reported that any intervention that came from outside the villages or communities were felt as not belonging to the citizens or members, but to the government and rejected the technologies involved.

Involvement of the receivers during the communication process by the extension agents elicits and sustains the interest of the receivers (farmers). Maintenance of continuous communication sustains the interest of the receivers too. The provision of follow up appointment has the same effect as maintenance of continuous communication. A good listener wins the respect of his audience. They see him as being genuinely interested in their problems and aspirations. Agbamu (2006) argues that senders should have listening ability. The use of entertainment enhances and sustains the interest of the audience. This also promotes their appreciation of the message.
Extension agents were rated on role performance as being very good (mean $=3.72$ ) in the knowledge of technologies. This also contributes to his credibility. The credibility of the communicator depends on the extent to which he is perceived as a source of valid assertions in terms of being knowledgeable about the subject matter he is presenting (Williams et al. 1984).

Olowu (1989) also noted that an agricultural extension agent should be theoretically and technically competent and that inadequacies in these areas could jeopardize the success of a development programme. They were rated as good (mean $=3.21)$ in the encouragement of to share information with others. This promotes diffusion of technology messages hence technologies. It will enhance information sharing among poultry farmers. Poultry farmers rated the extension agents as being fair $($ mean $=3.18)$ in the awareness of time limit. Awareness of time limit guards against untimely communication of innovations and during meeting with farmers, it guards against over burdening of farmers with too much information, which causes waning attention.

The extension agents were poor in frequency of farm visit (mean $=2.91)$ and availability to farmers (mean= 2.93). Frequency of extension contact with farmers and availability to farmers are very important as they promote better understanding of agricultural technology messages by farmers. It further enhances adoption of agricultural technologies. Ofuoku et al (2008) argue that the more extension agents visit farmers and educate them, the better they understand and adopt technologies. Asiabaka (1996) reported that frequency of extension contact influences the adoption behavior of farmers. Meanwhile, adoption is an index of effectiveness of technology messages.

The extension agent's attention can be needed at anytime of the day. This is why their availability to farmers is very important. This is so especially when the farmers have itching problems that they want the extension agent to help resolve. 
Table 1: Receivers' (poultry farmers') ratings of extension agents' human Relations communication skills and performance (senders' factors)

Senders factors

RatingMean Deci

Score $(\mathrm{X})$ sion

\section{Senders (EAs') human relation}

Feeling of togetherness with farmers $716 \quad 3.97 \quad$ V.G

Manner of approach to influence688 3.82 V.G acceptance of technology

General truthfulness and sincerity $\quad 697 \quad 3.87 \quad$ V.G

Communication behaviour and

skills

Display of empathy enquires

$\begin{array}{llll}\text { Use of key communicators } & 679 & 3.77 & \text { V.G }\end{array}$

$\begin{array}{llll}\text { Credibility } & 659 & 3.66 & \text { V.G }\end{array}$

Personality

Use of feedback system

$\begin{array}{lll}633 & 3.51 & \text { V.G }\end{array}$

$\begin{array}{llll}\text { Use of language and expression } & 661 & 3.67 & \text { V.G }\end{array}$

Clarity and comprehensibility $\quad 658 \quad 3.65$ V.G

Display of adequate communication671 3.72 V.G

skill generally

Involvement of clientele $\quad 656 \quad 3.64 \quad$ V.G

$\begin{array}{llll}\text { Maintenance of continuous578 } 3.21 \text { V.G } & \text { of }\end{array}$

communication

Provision of follow-up appointment $\quad 570 \quad 3.16 \quad$ F

$\begin{array}{llll}\text { Listening skill } & 582 & 3.23 & \text { V.G }\end{array}$

$\begin{array}{llll}\text { Use of entertainment } & 517 & 2.88 & \text { V.G }\end{array}$

Role performance

$\begin{array}{llll}\text { Frequency of farm visit } & 523 & 2.91 & \mathrm{P}\end{array}$

$\begin{array}{llll}\text { Availability to farmers } & 529 & 2.93 & \mathrm{P}\end{array}$

Knowledge of technologies $\quad 670 \quad 3.72 \quad$ V.G

Encouragement of farmers to share $578 \quad 3.21 \mathrm{G}$

information with others

Timeliness/awareness of time limit $\quad \begin{array}{llll}573 & 3.18 \quad \mathrm{~F}\end{array}$

Cut-off score $=3.0$ ( General average ratings-3.0 - 3.20

$=$ fair; $3.21-3.49=$ good; $\geq 3.50$ very good, $2.20-2.29$

$=$ poor,$<2.20=$ very poor)

\section{Senders' (extension agents') rating of poultry farmers' (receives') human relations, communication skills and role performance factors}

Table 2 indicates that the poultry farmers were very good at exhibiting truthfulness and sincerity (mean=3.51) when dealing-with other farmers and extension agents. They were seen as being fair in having the feeling of togetherness with extension agents and other poultry farmers

$(\mathrm{X}=3.13)$.

They were considered as being very good at the use of clear and comprehensible language and expression (mean $=4$. 07), participation question and enquiries (mean $=4.06)$, sending of feedback (mean=4.02), sharing of information with spouse and other farmers $(\mathrm{mean}=4.01)$. Comprehension of technology messages (mean=3.85) and listening ability (mean=3.62). They were however considered as being very fair in performance in the use of key communicators $($ mean $=3.85)$ and maintenance of continuous contacts with extension agents $($ mean $=3.03)$.

On role performance, the poultry farmers were considered to have put up a very good performance as members of poultry farmers groups (mean= 3.68). But were rated to have performed poorly in participation in agricultural shows and field trips (mean $=2.84$ ) and at encouragement of spouse sharing information with other farmers $($ mean $=2.81)$

The attributes of truthfulness and sincerity promoted trust on the poultry farmers by the Extension agents. This translated into integrity. This quality promotes a strong relationship between extension agents and farmers. Since they have been considered as being fair in the area of feeling of togetherness with other farmers and extension agents it means that they sometimes share their challenges with other farmers and extension agents and also share solution to challenges with them likewise.

On communication skill and behavior, the use of clear and comprehensible language and expression by the poultry farmers promoted right interpretation of messages and feedbacks by extension agents. Either interpretation of meanings of messages is promoted by the use of simple language and expression. According to Isife and Ofuoku (2008), use of simple language is one of the factors that establish comprehension. Here, the use of common words that have Concrete meanings is very important.

Participation in question and enquires enhances the comprehension of messages by the farmers and reveals to the extension agents, parts of technology messages that the learners difficult to understand. In all, unclear parts of the poultry technology messages are made clear to the farmers through their participation in questions and enquires. This is in consonance with Hunt (2006) who stated that farmers gained understanding of messages communicated through their participation in question and enquires. Technology message communication was informed by a theory that became a science of producing effective 
The poultry farmers' maintenance of continuous contact with extension agents is rated. Fair for the fact that there is an unfavorable extension agent-farmer ratio. Agbamu (2005) argued that the disproportionate extension agents to farm family ratio prevalent in developing countries had led to a situation in which many farmers do not benefit from the services of agricultural extension agents.

Their performance as members of poultry farmers' groups is very good. This implies that they as members of group collectively each other to meet their common goals for subscribing to such groups. According to Ogionwo and Eke (1999), people subscribe to groups because of their personal goals which they cannot achieve solely as an individual, but which they can attain by joining a group. Such goals may include access to credit, extension service and information.

The farmers were however, poor at meeting attendance. The implication is that most of them do not attend extension agents-farmers meeting. Since the extension agent to farmer ratio is poor, group extension method is mostly used, but the poultry farmers prefer face-to face contact with extension agents. Another reason is that meetings may have been fixed at odd times. Agbamu (2006), Isife and Ofuoku (2008) adjudged the individual or interpersonal (face- to-face) method as being the best. The farmers prefer this method because, according to Agbamu (2006), Isife and Ofuoku (2008), it gives the extension agents and farmers the opportunity to obtain first hand information.

They are also poor at attending agricultural shows and field trips. This is attributed to the fact that most of them consider the cost of transportation to such trips as being on the high side and they do not get information about them early enough to enable them prepare for such.

They are also poor at encouraging their spouse to share information with other farmers. This is mostly so with male poultry farmers. Most of the poultry farmers -are men and for cultural reasons, the association of their wives with other male farmers is highly restricted. Ofuoku (2010) discovered that culturally, men frown at frequent association between their spouses and male extension agents.

\section{Effectiveness of Poultry technology message as perceived by farmers}

The entire poultry teleology message (Table 3 ) except installation of ceiling fans (mean=2.36) were perceived as being very effective. There was none perceived as being not effective.

This is as a result of the fact that the messages were simple to understand, triable, observable, and compatible with the peoples' culture and have relative advantage over the ones previously

used. Another reason that is adduced to it is that they were sent with language that resonates with the target audience who not only support the extension goals but got motivated to act.

Tree planting, installation of fans and constant supply of water were climate change adaptation and mitigation measures communicated to farmers for adaptation and mitigation of excessively high temperature resulting from climate changes. Nwanjiuba et al. (2008) observed that temperature had a negative significant relationship with broiler production. This negative relationship is due to the fact that the mean annual temperature exceeded the optimum for broiler production. This is congruent with Teklewold et al. (2006), Saiki (2009) who discovered that farmers planted trees around pens to mitigate and adapt to climate change.

Installation of fan was to be effective $s$ it as an added cost of production. Water is in abundance as the water table in most part of the study area is high and rainfall is almost throughout the year.

Recycling of poultry droppings was found to be very effective as it massively solved the problem of accumulation of the droppings and air pollution. The gaseous emissions from poultry droppings also contribute to global warming. They were recycled by using them as manure for soil ammendrnent and fertilization. Teklewold (2006) opined that farmers found poultry droppings useful to them, as fertilizer for their supplementary crop farming activities 
Table 3: Effectiveness of poultry technology messages as perceived by farmers Technology messages

\begin{tabular}{|c|c|c|c|}
\hline Message & Score & $\begin{array}{l}\text { Mean } \\
(\mathrm{X})\end{array}$ & Decision \\
\hline \multicolumn{4}{|l|}{ Climate change adaptation } \\
\hline Tree planting & 579 & 3.21 & $\mathrm{HE}$ \\
\hline Installation of fan & 425 & 2.36 & E \\
\hline Constant supply of fresh water & 569 & 3.16 & $\mathrm{HE}$ \\
\hline \multicolumn{4}{|l|}{ Waste management } \\
\hline $\begin{array}{l}\text { Recycling of droppings } \\
\text { Health management }\end{array}$ & 572 & 3.18 & $\mathrm{H} \mathrm{E}$ \\
\hline $\begin{array}{l}\text { Bird flu prevention } \\
\text { Prevention of predators }\end{array}$ & 496 & 2.76 & $\mathrm{E}$ \\
\hline Use of sliced garlic & 512 & 2.84 & HE \\
\hline \multicolumn{4}{|l|}{ Exotic (improved) breeds } \\
\hline Abro & 457 & 2.54 & HE \\
\hline Arboracre & 469 & 2.64 & $\mathrm{HE}$ \\
\hline Harco & 500 & 2.78 & $\mathrm{HE}$ \\
\hline $\begin{array}{l}\text { Isa brown } \\
\mathrm{E}\end{array}$ & 521 & 2.89 & $\mathrm{H}$ \\
\hline Shaver star cross & 495 & 2.75 & $\mathrm{HE}$ \\
\hline Black Olympia & 460 & 2.56 & $\mathrm{HE}$ \\
\hline
\end{tabular}

and selli them to arable crop farmers.

Bird Flu (Avian influenza) prevention measures were found effective as the outbreak has died down in the study area. According toCenter for Disease Control (CDC) (2009), the incidences of avian influenza epizootic outbreak has reduced. This is as a result of the preventive measures which poultry farmers adhered to.

Garlic was also found effective by farmers because when they applied it as contained in the message, snakes were no longer visiting their farms. This confirms the findings of Teklewold (2006) who observed that poultry farmers placed garlic around poultry pens to repel snakes and it is efficacious.

Technology message on improved breeds of chicken were found to be effective as these hybrids were seen to be fast growing, good layers and resistant to diseases. Wanjiuba et al (2008) discovered that the hybrids adopted by farmers were found to be highly resistant to diseases and adverse climatic conditions.

\section{Level of adoption of poultry production technologies \\ Most $(73.3 \%)$ of the farmers adopted above 8}

Table 4: Distribution of Farmers according to Poultry Production Technologies Adoption Level

Adoption level Frequency Percentage(\%)

Low (1-5 technologies) $14 \quad 7.8$

Medium (6 -8 technologies) $34 \quad 18.9$

High ( $>8$ technologies $) \quad 132 \quad 73.3$

*Significant at 5\% level of significant (2 - tailed)

technologies, $19.9 \%$ adopted between 5 and 8 technologies, while $7.8 \%$ adopted 1-5 technologies (Table 4). This shows that the adoption level was generally high as $73.3 \%$ of the respondents fell under the category of high adoption level.

They all adopted bird flu prevention and control measures. From observation, the extension agents applied Rogers' (1975) and (1983) protection motivation theory (PMT) in delivering the messages on bird flu prevention. PMT contends that individuals must perceive something to be risky or harmful to be motivated to protect one's self (Houser et al. 2009). As PMT suggests, Roger (1983), that perceived risk is a motivating factor, especially when delivered via a fearful message combined with message self efficacy.

The results of the adoption level conforms the perception of the farmers on the effectiveness of the poultry technology messages. Level of adoption is an index of effectiveness of technology messages.

Influence of extension agents' and farmers' communication skills of poultry production technology messages

This was determined by the hypothesis

Hot: There is no significant relationship between poultry production technology adoption and communication skills of extension agents and farmers.

The results of the hypothesis (Table 5) indicate that adoption of poultry technology messages significantly and positively correlated with the communication factors of extension agents $(\mathrm{r}=$ $0.877)$ farmers $(r=0.797)$ at $\alpha 0.05$. The communication session agents and farmers have contributed to the effectiveness of the poultry technology messages, since adoption level of the poultry technologies is an index of effectiveness of poultry technology messages. This agrees with Isife and Ofuoku (2008) who state that communication skills of sender (extension agent) and the receiver (poultry 
Table 5: Relationship between adoption of poultry technology messages and communication skills of extension agents and farmers

\begin{tabular}{|c|c|c|}
\hline & 2 & 3 \\
\hline 1 Adoption of poultry technologies & $1.000877^{*}$ & $.797 *$ \\
\hline $\begin{array}{l}2 \text { Communication skill of extension } \\
\text { agent }\end{array}$ & $.877 * 1.000$ & .384 \\
\hline 3 Communication skill of farmers & $.797 * .384$ & 1.000 \\
\hline
\end{tabular}

farmers) affect the effectiveness message passed across or exchanged or traded.

This significant correlation shows that enhanced communication skills of extension agents and farmers are accompanied by increased adoption. The implication is that high level $\mathrm{t} 7$ of communication skill could help to stimulale and poultry technologRespectively. This translates into increased yield and income for the farmers. This also indicia's that as extension agents' and poultry farmers' communication skills are enhanced, adoption of improved poultry production practices is promoted.

\section{CONCLUSION AND RECOMMENDATIONS}

It is obvious that the reception of poultry production depends to a large extent, on the communication skills of the senders (extension agents) and receivers (poultry farmers). The Extension Agents were rated generally as being good at human relations, communication skills and role performance by the poultry farmers, while the extension agents also rated the poultry farmers generally as being good at human relations, communication skills and role performance. The poultry production technology messages disseminated to the farmers were effective and the level of adoption of these technologies confirmed that fact. The communication skills of both the extension agents and the farmers influenced the effectiveness of the poultry technology messages. The level of adoption of poultry technologies proved to be an index of effectiveness of the poultry production technology messages.

In view of the findings, the following recommendations are made:

1. Extension agent's should endeavor to provide follow-up appointment with farmers always.
2. Move qualified people should be trained encouraged and employed as extension agents so as to solve the problems of unavailability to farmers and poor performance in farm visits by extension agents.

3. Extension agents should try as much as possible to be timely and talk within limited time range so that the technologies can solve the problems they are meant for and avoid waning attention by farmers respectively.

4. Farmers should be encouraged to participate in field trips

5. Farmers should be encouraged to allow their spouses to share Information. With other farmers as this will lead to information exchange that will be beneficial to them.

6. Farmers should be educated on the beneficial of meeting attendance. Farmers and extension agents should sustain their communication skills.

\section{REFERENCES}

Adedoyin SF 2004 Plentiful agricultural resources, but limited andragogical transmission. Thirtythird 33 Inaugural lecture, Ago-Iwoye: Olabisi Onabanjo University.

Adefuye BO and Adedogin SF 1993 Adoption of rent: a factor influencing the effectiveness of the contact farmer strategy on diffusion of innovations in Ogun State, Nigeria. Journal of Rural extension and Development. 1(2\&3), 6975.

Agbamu JU 2005 Challenges and prospects of agricultural extension in Nigeria. In Adedoyin, S.F. (Ed). Agricultural extension in Nigeria. Extension Society of Nigeria. pp 159-169.

Agbamu JU 2006 Essentials of agricultural communication in Nigeria Lagos: Maithouse Press Ltd.

Asiabaka CC 1996 Factors influencing the a doption of cassava plant protection among farmers in Nigeria Benin: ESCAP.

CDC 2009 Avian Inlfuenza: Curren situation. Available at: http//www. cdc. gov/ flu/avianloutbreak/current.htm.

Houser ML, Burns ME and Driver NR 2009 Communicating with students about STIs: Assessing message effectiveness and preferred source and channel. Human Communication, 10 (3), 311-328.

Hunt JU 2006 Defining effective message. Technical Assistance Bulletin. Washington. D.C. Centre for Sustainable Agricultural Policy (CSAP). 
Isife BJ and Ofuoku AU 2008 Communication in agricultural extension and rural development: concepts and methods. Owerri: Springfield publishers Ltd.

Izunobi ND 2002 Poultry husbandry Ihiala, Nigeria: Mgbe-BPP Publishing House.

Niehaus M 2006 A voiding mixed messagesimproved communication. Windhock: NamibianEconomist.Availableat:http:// www.Economist t.com.Na/2001/220601/ story $13 \mathrm{htm}$.

Nwanjiuba CU, Onyeneke R and Munonye J 2008 Climate change: perception and adaptation by poultry farmers in Imo State. In Nwanjiuba, C.U. (ed). Climate change in Nigeria. Hohienhen: University of Hohienhen. Pp 324-3

Ofuoku A U 2010 Communication process and effectiveness of agricultural technology messages in poultry production in Delta State, Nigeria. Unpublished $\mathrm{PhD}$ post-field seminar. Department of Agricultural Economics and Extension, Rivers State Unit of Science and Technology, Port Harcourt, Nigeria.

Ofuoku AU, Olele NF and Emah GN 2008 Determinant of adoption of improved fish production technologies among fish farmers in Delta State, Nigeria. Journal of Agricultural Education and Extension. 14 (4), 297-306.

Olowu TA 1989 Extension communication strategies role of communication in forest protection. A paper presented at the National Workshop on Forestry Extension Services. In Manpower Development Centre, Olowa, Ondo State, Sept. 25-29.

Ofuoku AU 2011 Gender representation in extension workforce in Delta State and its implication for extension advisory services. Journal of Tropical Agricultural Research and Extension, forthcoming.
Ogionwo 0 And Eke SE 1999 Introduction to Sociopsychology Owerri: Springfield Publishers Ltd.

Quarmyne W 1991 Towards a more participatory environment: cross-linking establishment and alternative media. Ottawa: IDRC.

Rogers RW 1975 A protection motivation theory of fear, appeals and attitude change. Journal of Psychology, 26, 99-114.

Rogers RW 1983 Cognitive and physiological process sin fear, appeals, and attitude change: A revised theory of protection motivation. In Cacioppo J and Pethy R (eds). Social Psychophysiology. New Yor: Guilford pp 153-176.

Roling N 1990 Makin the link: agricultural research -technology transfer for developing countries Boulder, Colorado: West View Press.

Saiki P 2009 Determinants of adaptation to climate change among arable farmers in Edo State, Nigeria.Unpublished B.Agric. Project,Department of Agricultural Economics and Extension,Delta State University,Abraka,Nigeria.

Teklewold H Dadi L and Dana N 2006 Determinants of adoption of Poultry technologies: a double-hurdle approach Livestock. Research for Rural Development .1 (3), $1-15$.

Tladi FM 2004 Competency requirements of extension agents in easter Botswana. Journal of Extension Systems, 20, 32- 41.

Waisboard S 2005 Family tree of theories, methodologies and strategies in development communication. New York: Reckefeller Foundation.

Williams SKT Fenley JM and Williams CB 1988 Manual for agricultural extension workers in Nigeria. Ibadan: University of Ibadan. 